\title{
RESPONSE
}

\section{Reflections on the Contributions of Peter Collins and the Death of Humanity Behind Bars Justin Piché}

Z very single day we are reminded that human beings are capable of great acts of generosity and extreme acts of cruelty. While these moments tend to define our time on earth, it is the unremarkable, mundane, everyday things we think, say and do that embody and convey who we have been, what we have become, and who we want to be. Like the seasons where the cold wind turns into many flowers that bloom, where the heat gives way to leaves that eventually fall to the ground which turns to snow, we change, we are 'unfinished', we become renewed (Mathiesen, 1974). And in those seas of change lies hope that we can abolish what we consider to be unjust, work towards what we consider to be just, so that we may live at peace with others and ourselves as we strive for better days always out of reach, because we can always better (Pepinsky, 2007). As long as there is this hope, life has meaning, life has a purpose, life becomes more than about survival, life becomes about thriving to the degree that is structurally possible in this world rife with inequality and injustice (Davis and Mendieta, 2005).

The Peter Collins I came to know through his artwork and writing for the Journal of Prisoners on Prisons when I first became involved in the publication and our many letters never gave up on this hope that the world and the beings that inhabit it, including himself, could be better. He denounced the cruelty in our midst, notably that of the Canadian carceral state (e.g. Collins, 2008a; Collins, 2008b) and even his own (Duffy, 2015), which most, including myself, are not able to do at the best of times. He, like many "lifers" (Irwin, 2012), was accountable and held others to account. He resisted the temptation to just go with the flow. He decided to fight for what is right, to fight for a world where we treat each other with unwavering compassion so that we do not succumb to the poisons of fear, spite and vengeance.

Unfortunately, such toxins have again become integral discursive ingredients in the kool-aid many choose to drink to the point of intoxication and delight (see Webster and Doob, 2015). My heart is heavy, disturbed by the fact that Peter, who suffered from inadequate care for cancer and other health issues behind bars, was denied compassionate release and that the "Life Means Life" proposal by the Conservatives would, if made law, 
remove parole eligibility for certain offences, thereby officially enshrining the other death penalty in Canada. That such a measure is celebrated in some circles is wrong and it must be resisted.

For all of colonial Canada's faults, I believe I still live in a country where the value of a life, mine or yours, is not reduced to our worst actions. I believe that human beings are capable of improvement, of change and of doing good in this world. I believe that it is wrong to condemn fellow human beings to die in prison, when history has taught us that this kind of demonization and dehumanization can only lead to great atrocities in the name of higher loyalties that deserve no loyalty at all (Bauman, 2001). What is on the line here is not just the fate of those in prison, but of us all, of our humanity.

In memory of Peter and others who have shared his fate, I echo JPP contributors whose work is included in this issue and previous ones who call upon us to mobilize an effective resistance that says "no" (Mathiesen, 2008). "No" to deaths in custody. "No" to prisons as a catch-all response to complex conflicts and harms that we criminalize and punish today. And "no" to bars that divide and deprive all of us of our common humanity.

Thank you Peter for striving toward a better world in impossible circumstances and for inspiring us to do the same.

\section{ABOUT PETER COLLINS}

Serving a life sentence in prison, Peter Collins knew he had to come to terms with the consequences of his actions and so dedicated himself to working for positive social change. Since the late 1980s, when the official position of the Correctional Service of Canada was that intravenous drug use, tattooing, and sex were illegal - therefore not happening - until today when prisoners continue to be denied access to clean needles and syringes, Peter's tireless efforts to defend the health and human rights of prisoners often led to strained relationships with prison officials, undermining his efforts to get paroled. While in prison, Peter earned an honours diploma in Graphic and Commercial Fine Arts, as well as a certification as a Frontier College ESL tutor. He was an Alternatives to Violence Project facilitator and Peer Education Counsellor. Peter was instrumental in setting up a Peer Education Office in Bath Institution and advocated on behalf of fellow prisoners on issues ranging from health access to employment. He also wrote a book helping prisoners prepare for 
successful and safe release into the community. Regularly donating his time, expertise, and artwork to numerous charities and social justice initiatives, Peter's dedication contributed to improved health and safety in the prison system, and by extension, in the community at large. Peter passed away in August 2015, days after Prisoners' Justice Day.

\section{REFERENCES}

Bauman, Zygmunt (2001) Modernity and the Holocaust, Ithaca: Cornell University Press.

Collins, Peter (2008a) "Education in Prison or The Applied Art of "Correctional" Deconstructive Learning”, Journal of Prisoners on Prisons, 17(1): 71-90.

Collins, Peter (2008b) "The Continuing Story of Spiegelgrund: Mental Health, Compassion, Awareness and Incarceration", Journal of Prisoners on Prisons, 17(2): 6-15.

Davis, Angela Y. and Eduardo Mendieta (2005) Abolition Democracy: Beyond Empire, Prisons and Torture, New York: Seven Stories Press.

Duffy, Andrew (2015) "Final confession: Man who killed Ottawa police officer reveals full story of his crime", Ottawa Citizen - June 26.

Irwin, John (2012) Lifers: Seeking Redemption in Prison, New York: Routledge.

Mathiesen, Thomas (2008) "The Abolitionist Stance”, Journal of Prisoners on Prisons, 17(2): 58-63.

Mathiesen, Thomas (1974) The Politics of Abolition, London: Martin Robinson.

Pepinsky, Hal (2007) Peacemaking: Reflections of a Radical Criminologist, Ottawa: University of Ottawa Press.

Webster, Cheryl M. and Anthony N. Doob (2015) 'US Punitiveness 'Canadian Style'? Cultural Values and Canadian Punishment Policy”, Punishment \& Society, 17(3): 299-321.

\section{ABOUT THE AUTHOR}

Justin Piché is an Assistant Professor in the Department of Criminology and has held various roles with the JPP since 2007. His research examines the reproduction of imprisonment as a dominant response to criminalized conflicts and harms in state and popular discourses, as well as explores strategies to work towards abolishing punitive logics, policies and practices. 